\title{
Feeding of wheat bran and sugar beet pulp as sole supplements in high- forage diets emphasizes the potential of dairy cattle for human food supply
}

\author{
P. Ertl, ${ }^{* 1}$ Q. Zebeli, $\uparrow$ W. Zollitsch, ${ }^{*}$ and W. Knaus* \\ *Department of Sustainable Agricultural Systems, Division of Livestock Sciences, BOKU-University of Natural Resources \\ and Life Sciences Vienna, 1180 Vienna, Austria \\ †Institute of Animal Nutrition and Functional Plant Compounds, Department for Farm Animals and Veterinary Public Health, \\ University of Veterinary Medicine, 1210 Vienna, Austria
}

\begin{abstract}
Besides the widely discussed negative environmental effects of dairy production, such as greenhouse gas emissions, the feeding of large amounts of potentially human-edible feedstuffs to dairy cows is another important sustainability concern. The aim of this study was therefore to investigate the effects of a complete substitution of common cereal grains and pulses with a mixture of wheat bran and sugar beet pulp in a highforage diet on cow performance, production efficiency, feed intake, and ruminating behavior, as well as on net food production potential. Thirteen multiparous and 7 primiparous mid-lactation Holstein dairy cows were randomly assigned to 1 of 2 treatments in a change-over design with 7 -wk periods. Cows were fed a high-forage diet (grass silage and hay accounted for $75 \%$ of the dry matter intake), supplemented with either a cereal grain-based concentrate mixture $(\mathrm{CON})$, or a mixture of wheat bran and dried sugar beet pulp (WBBP). Human-edible inputs were calculated for 2 different scenarios based on minimum and maximum potential recovery rates of human-edible energy and protein from the respective feedstuffs. Dietary starch and neutral detergent fiber contents were 3.0 and $44.1 \%$ for WBBP, compared with 10.8 and $38.2 \%$ in CON, respectively. Dietary treatment did not affect milk production, milk composition, feed intake, or total chewing activity. However, chewing index expressed in minutes per kilogram of neutral detergent fiber ingested was $12 \%$ lower in WBBP compared with CON. In comparison to $\mathrm{CON}$, the human-edible feed conversion efficiencies for energy and protein, defined as human-edible output per human-edible input, were 6.8 and 5.3 times higher, respectively, in WBBP under the maximum scenario. For the maximum scenario, the daily net food production (human-edible output minus human-edible input) increased from $5.4 \mathrm{MJ}$ and $250 \mathrm{~g}$ of crude protein per
\end{abstract}

Received August 19, 2015.

Accepted November 3, 2015.

${ }^{1}$ Corresponding author: paul.ertl@boku.ac.at cow in CON to $61.5 \mathrm{MJ}$ and $630 \mathrm{~g}$ of crude protein in the WBBP diet. In conclusion, our data suggest that in forage-based dairy production systems, wheat bran and sugar beet pulp could replace common cereal grains in mid-lactation dairy cows without impairing performance, while strongly increasing human-edible feed conversion efficiency and net food production index.

Key words: human-edible, feed conversion efficiency, nonforage fiber source, food security, by-product

\section{INTRODUCTION}

Projected increases in the world's global food demand will increase public pressure on animal agriculture because, besides concerns about the environmental effects of livestock production, the generally low efficiency of converting feed nutrients into animal products is a major issue of criticism. Scientists have therefore pointed out the necessity of feeding less human-edible feeds to livestock in the future (FAO, 2011; Eisler et al., 2014), which could increase net food production (NFP), defined as human-edible output via animal products minus potentially human-edible input via feedstuffs. A recent evaluation of 30 Austrian dairy farms has shown that their average NFP is slightly positive for energy and protein, but that there is great potential for improvement (Ertl et al., 2015a). In the trade-off between feeding for high animal performance and reducing human-edible inputs at the same time, fiber-rich by-products offer promising opportunities, especially in terms of energy supply (Bradford, 1999; Gill, 2013). In fact, fiber-rich by-products have long been used in dairy cattle nutrition, both as alternative feedstuffs to forage, or as alternative fiber [nonforage fiber sources (NFFS)] and energy sources for high-yielding dairy cattle (Swain and Armentano, 1994; Bradford and Mullins, 2012; Dann et al., 2014). However, data on NFFS usage in high-forage diets, as well as quantitative data on the potential of NFFS to increase NFP and human-edible feed conversion efficiency (heFCE), are limited. The heFCE expresses the human-edible output through the animal product per human-edible input in feedstuffs. 
In an earlier feeding trial, we substituted a mixture of industrial by-products for a mixture of commonly used concentrates as energy and protein sources and found that this substitution could increase the human-edible feed conversion efficiency by 4 and 2.7 times for energy and protein, respectively, without impairing milk production (Ertl et al., 2015b). However, the by-products included in this earlier trial were still rich in $\mathrm{NE}_{\mathrm{L}}$ and $\mathrm{CP}$ (to achieve an isoenergetic and isonitrogenous experimental diet), which is most likely not true for the majority of common by-products that are available in large quantities.

With an annual production of nearly 3 million tonnes of sugar beets and close to 1.5 million tonnes of wheat, these were 2 of the top 5 commodities produced in Austria in 2013. With an annual production of nearly 250 million tonnes of sugar beets and over 600 million tonnes of wheat worldwide, these commodities are also among the most commonly cultivated crops around the world (FAO, 2015). During processing of sugar beets and wheat, about $20 \%$ of the DM results in the by-products sugar beet pulp and wheat bran, respectively, which indicates their high availability (Fadel, 1999). Whereas several studies have investigated the use of sugar beet pulp in dairy cow diets (Bhattacharya and Lubbadah, 1971; Hemingway et al., 1986; Voelker and Allen, 2003), only limited information is available for wheat bran. In a recent study, Dann et al. (2014) formulated lowerstarch diets by partially replacing corn with sugar beet pulp and wheat middlings and did not find measurable effects on ruminal fermentation, chewing behavior, or milk performance. However, in Dann et al. (2014), grass silage plus hay accounted for only $23.5 \%$ of the diet DM, whereas this is usually well over $50 \%$ for typical Austrian dairy rations. Replacing concentrates with NFFS in less fermentable diets, however, might reduce DMI and productivity (Bradford and Mullins, 2012).

Therefore, the objective of the current study was to examine the effect of feeding a mixture of wheat bran and sugar beet pulp as sole dietary supplements in a high-forage diet for mid-lactation dairy cows. We hypothesized that replacing the grain concentrate portion in a high-forage diet (75\% of total DMI) with wheat bran and sugar beet pulp would not impair milk performance data, DMI, or chewing activity in lowperforming dairy cows, but we expected strong effects on NFP and efficiency indicators.

\section{MATERIALS AND METHODS}

\section{Experimental Design and Animals}

Thirteen multiparous and 7 primiparous Holstein cows were used in an experiment conducted as a change-over design with 2 consecutive experimental periods of equal duration (7 wk each). Cows were housed in a cubical housing system with Calan gates (American Calan Inc., Northwood, NH) for individual feeding at the organic dairy farm of the Secondary Agricultural and Forestry School Ursprung in the province of Salzburg, Austria ( $570 \mathrm{~m}$ above sea level, 1,250 $\mathrm{mm}$ annual precipitation, $8.5^{\circ} \mathrm{C}$ average annual temperature). At the beginning of the experiment, cows were randomly assigned to 1 of 2 treatment groups of 10 cows each, according to their average $( \pm \mathrm{SD})$ milk yield $(26.2 \pm 6.0 \mathrm{~kg}), \mathrm{BW}(661 \pm$ $54 \mathrm{~kg})$, DIM (117 \pm 113$)$, and number of lactations (3.1 \pm 2.4 ).

Prior to the experiment, all cows were fed grass silage, corn silage, and hay derived from permanent grassland at a ratio of approximately $0.75: 0.15: 0.10$ on a DM basis for ad libitum intake. In addition, cows received a mixture of commercially produced concentrates in pelleted form via an automatic feeding station depending on the milk yield of the previous week (up to a maximum rate of $8 \mathrm{~kg} / \mathrm{d}$ ). Cows were allowed to adapt to the respective diet during the first 2 wk of each experimental period and measurements were taken in each period between wk 3 and 7 . Immediately after the end of the first experimental period, the treatment groups were switched and the adaptation period for the second period began. The week before the start of the first experimental period served as adaptation time for Calan gates. No invasive procedures were performed on the animals and the provincial veterinary authority Salzburg approved the feeding trial.

\section{Diets and Feeding Procedure}

Two TMR differing in the type of concentrate were compared in this experiment. The TMR were prepared once a day and offered twice daily (0500 and $1500 \mathrm{~h}$ ) in an amount to ensure 5 to $10 \%$ feed refusals. Composition of the 2 different diets, as well as the estimated potentially human-edible fraction of each ingredient (Ertl et al. 2015a), are shown in Table 1. Dietary treatments were not formulated to be isoenergetic or isonitrogenous, but to obtain the same forage-to-concentrate ratio of $0.75: 0.25$ on a DM basis. Forage for both diets consisted of first-cut grass silage, and second and thirdcut hay (different cuts of hay at equal proportions). About $50 \%$ of the forages (hay and silage) were derived from permanent grassland (composition approximately $50 \%$ grasses, 30\% herbs, and 20\% legumes) and the other $50 \%$ from perennial clover-grass (about 50\% grasses and $50 \%$ clover). In addition to forage, the control diet $(\mathbf{C O N})$ included a commercially produced concentrate mixture, commonly used in Austrian organic dairy production (Table 1). The experimental 
Table 1. Composition of diets and the range (minimum to maximum) of potentially human-edible fractions of various dietary ingredients

\begin{tabular}{|c|c|c|c|c|}
\hline \multirow[b]{2}{*}{ Item, $\%$ of DM } & \multicolumn{2}{|c|}{ Diet $^{1}$} & \multicolumn{2}{|c|}{ Human-edible fraction, ${ }^{2} \%$} \\
\hline & $\mathrm{CON}$ & WBBP & Minimum & Maximum \\
\hline Grass silage, first-cut & 44.8 & 44.8 & 0 & 0 \\
\hline Hay, second and third-cut & 30.0 & 30.0 & 0 & 0 \\
\hline Barley grain & 6.50 & - & 40 & 80 \\
\hline Triticale & 4.95 & - & 60 & 100 \\
\hline Corn & 4.25 & - & 70 & 90 \\
\hline Rye & 3.75 & - & 60 & 100 \\
\hline Field beans & 3.75 & - & 70 & 90 \\
\hline Molasses & 0.75 & - & 0 & 0 \\
\hline Limestone & 0.68 & - & 0 & 0 \\
\hline Sodium bicarbonate & 0.25 & - & 0 & 0 \\
\hline Mineral and vitamin premix ${ }^{3}$ & 0.32 & 0.20 & 0 & 0 \\
\hline Wheat bran & - & 14.0 & 0 & 20 \\
\hline Sugar beet pulp & - & 11.0 & 0 & 0 \\
\hline
\end{tabular}

diet included only wheat bran and dried sugar beet pulp (WBBP) as supplements in addition to forage, minerals, and vitamins (Table 1). All feedstuffs other than forages were obtained in ground (hammer milled) and premixed form from a commercial feed mill.

\section{Data Collection and Analytical Procedure}

Daily milk yield was recorded digitally throughout the whole experiment during the milking at 0600 and $1630 \mathrm{~h}$ in a $2 \times 3$ herringbone milking parlor. Individual feed intake was determined manually during 6 -d recording periods in wk 3 and 7 of each experimental period using Calan gates. The DMI was determined as the daily difference between feed provision and feed refusals. The DM contents of the fresh TMR and of feed refusals were determined on 3 out of $6 \mathrm{~d}$ per recording period by drying in a forced-air oven at $100^{\circ} \mathrm{C}$ for 32 h. During these recording periods, a digital livestock platform scale was used to determine cows' live weight by weighing the cows immediately after 2 consecutive milkings and calculating the mean. Individual milk samples were taken weekly from 2 consecutive milkings and conserved with Bronysolv (ANA.LI.TIK. Austria, Vienna, Austria) until analysis for fat, protein, lactose, milk urea concentrations, and SCC via Milkoscan (Foss Electric, Hillerød, Denmark). During wk 3 and 7 of each experimental period, 2 samples of the fresh TMR and 1 sample of the feed refusals per group (all samples pooled over 2 consecutive days) were taken for analysis of feed composition. Samples were vacuum packed and stored at $-20^{\circ} \mathrm{C}$ until analysis at a commercial laboratory, using methods described by VDLUFA (1993; with method numbers in parentheses) for CP (4.1.2), ether extract (5.1.1), starch (7.2.1), NDF (6.5.1), ADF (6.5.2), ADL (6.5.3), and crude ash (8.1).

Chewing behavior was recorded using noseband sensors (RumiWatch System, ITIN + HOCH GmbH, Liestal, Switzerland). This system consists of a vegetable oil-filled tube, a pressure sensor, an accelerometer, an internal data storage device, and a wireless transmitter integrated into a halter. The cow's chewing activity was recorded via pressure changes in the oil-filled tube at a frequency of $10 \mathrm{~Hz}$. Chewing behavior was measured for each cow for a 5-d period in each experimental period during 1 of the 2 DMI recording periods (half of the cows per treatment were equipped with a $\mathrm{Ru}-$ miWatch halter in wk 3 of each experimental run and the other half in wk 7). Raw data were saved on the internal storage device for the 5 -d measuring period, downloaded via USB onto a computer and analyzed via RumiWatch converter 0.7.3.11 (ITIN + HOCH GmbH, Liestal, Switzerland) on a 24-h basis (starting $1500 \mathrm{~h}$ ).

\section{Data Calculation}

Human-edible feed conversion efficiencies were calculated for 2 different scenarios [minimum (min) and maximum $(\max )]$ on a $\mathrm{CP}$ and gross energy basis, respectively, and were defined as daily human-edible output per daily human-edible input (Wilkinson, 2011). To calculate human-edible inputs, either min or max proportions of potentially human-edible fractions of feedstuffs were presumed (Table 1). As described in detail in Ertl et al. (2015a), these minimum and maximum human-edible fractions represent the range for 
the potential recovery rate of human-edible nutrients from feedstuffs based on today's technology. Due to similar nutrient composition and potential food usages, the values for the human-edible fractions of peas were taken for field beans. Molasses was considered as non-human-edible. In Ertl et al. (2015a), all the feedstuffs fed in the present feeding trial under the min scenario, except field beans, were assumed to have the same extraction rates for energy and protein. Therefore, potential extraction rates for protein were taken for the calculation of the potential human-edible input via feedstuffs for both protein and energy. The commercial feed supplier of the concentrate feeds provided the GE and CP contents of the individual feedstuffs used in our study for the calculation of human-edible inputs. To calculate heFCE and NFP for other studies in the discussion, $\mathrm{GE}$ and $\mathrm{CP}$ contents of the respective feedstuffs were obtained from current database (INRA et al., 2015). The human-edible output comprised the amount of gross energy and $\mathrm{CP}$ in the milk. To calculate the energy content of the milk, the formula described by NRC (2001), including fat, protein, and lactose content of the milk, was used with the factor 4.184 for the conversion of calories to joules. For the min scenario, heFCE could not be calculated for the WBBP diet because the estimated human-edible input was zero. Net food production (MJ of gross energy/d and $\mathrm{kg}$ of $\mathrm{CP} / \mathrm{d}$ ) was defined as human-edible output (MJ of gross energy and $\mathrm{kg}$ of $\mathrm{CP}$, respectively) minus human-edible input. Human-edible input and humanedible output were calculated as described above for heFCE. Nitrogen efficiency was calculated as $\mathrm{N}$ in the milk in percent of $\mathrm{N}$ intake.

\section{Statistical Analysis}

Data were analyzed using PROC MIXED of the statistical software package SAS 9.2 (SAS Institute Inc., Cary, NY) using the following model:

$$
\begin{gathered}
\mathrm{Y}_{i j k l m n o p}=\mu+\mathrm{T}_{j}+\operatorname{day}_{k}+\mathrm{P}_{l}+\mathrm{DL}_{m}+\mathrm{LW}_{n}+\mathrm{LG}_{o} \\
+\mathrm{LWC}_{p}+\mathrm{T}_{j} \times \mathrm{P}_{l}+\operatorname{cow}(\mathrm{T})_{i j}+\varepsilon_{i j k l m n o p},
\end{gathered}
$$

where $\mathrm{Y}_{\text {ijklmnop }}=$ dependent variable; $\mu=$ overall mean; $\mathrm{T}=$ fixed effect of treatment $j(\mathrm{CON}$ or $\mathrm{WBBP})$; day $=$ fixed effect of measurement day $k$ in the feeding trial; $\mathrm{P}=$ continuous effect of daily milk yield $l$ (not for milk performance and chewing activity); DL = continuous effect of day of lactation $m$ (not for chewing activity); $\mathrm{LW}=$ continuous effect of live weight $n$ (only for milk performance, feed and nutrient intake, and chewing activity); $\mathrm{LG}=$ fixed effect of lactation group $o$ (pri- miparous or multiparous; only for milk performance, milk composition, and live weight change); LWC = continuous effect of live weight change (only for milk composition); $\mathrm{T} \times \mathrm{P}=$ effect of interaction between treatment $j$ and performance $l$ (only for milk composition); $\operatorname{cow}(\mathrm{T})=$ random effect of cow $i$ within treatment $j ; \varepsilon=$ random error. Due to a lack of significance, the effect of sequence of treatments was excluded from the final model.

Different covariance structures were tested to account for repeated measures on time, and the one with the Bayesian information criterion closest to zero was chosen for the final model (Littell et al., 1998). Presented values are least squares means and differences between treatments with $P<0.05$ were considered significant.

\section{RESULTS AND DISCUSSION}

\section{Feed Composition and Nutrient Intake}

The chemical composition of the diets is presented in Table 2. As expected, fiber content was higher in WBBP, whereas starch content was lower compared with the CON diet. This reflects the typical differences in the nutrient composition of NFFS such as wheat bran and sugar beet pulp when compared with grain concentrates (Bradford and Mullins, 2012). Even though higher in the CON diet (10.8 compared with $3.0 \%$ of DM in WBBP), the starch content in both diets was relatively low when compared with diets for high-yielding dairy cows, where the starch level is usually between 20 and $30 \%$ of the diet DM (Chase, 2007). However, rumen microbes do not necessarily depend on starch supply, as they can use other rumen-fermentable carbohydrate sources (Chase, 2007). In a recent in vitro study, fibrous by-products showed potential as an adequate substitute for cereal grains and pulses with regard to fermentation patterns and enhancing microbial activity (Ertl et al., 2015c).

Total DMI and DMI as a percent of BW did not differ between treatments, as shown in Table 3. When comparing diets differing in their starch content via increasing the inclusion rate of sugar beet pulp and wheat middlings while reducing the amount of corn, Dann et al. (2014) also reported no effects on DMI whereas Voelker and Allen (2003) found reduced DMI when sugar beet pulp was substituted at $24.3 \%$ of the DM for high-moisture corn. As a result of the similar DMI, differences in the nutrient composition of the diets led to a higher NDF $(+18 \%)$ and lower starch $(-73 \%)$ intake for cows in the WBBP group compared with cows in CON. Intake of ether extract differed between treatments, but differences $(37 \mathrm{~g} / \mathrm{d}, P<0.001)$ were likely too small to be of biological significance. 
Table 2. Chemical composition $( \pm \mathrm{SD})$ of forages and complete diets (\% of DM, unless stated otherwise)

\begin{tabular}{|c|c|c|c|c|}
\hline \multirow[b]{2}{*}{ Item } & \multirow[b]{2}{*}{ Grass silage } & \multirow[b]{2}{*}{ Hay } & \multicolumn{2}{|c|}{ Diet $^{1}$} \\
\hline & & & $\mathrm{CON}$ & WBBP \\
\hline DM, $\%$ of fresh matter & $30.0 \pm 0.6$ & $91.5 \pm 1.5$ & $42.0 \pm 2.1$ & $41.3 \pm 1.2$ \\
\hline $\mathrm{CP}$ & $13.6 \pm 0.4$ & $13.9 \pm 0.5$ & $13.4 \pm 0.4$ & $13.8 \pm 0.4$ \\
\hline $\mathrm{uCP}^{2}$ & $13.2 \pm 0.1$ & $12.7 \pm 0.2$ & $14.1 \pm 0.2$ & $14.0 \pm 0.2$ \\
\hline $\mathrm{RNB},{ }^{3} \mathrm{~g} / \mathrm{kg}$ & $0.6 \pm 0.6$ & $1.8 \pm 1.0$ & $-1.0 \pm 0.4$ & $-0.3 \pm 0.2$ \\
\hline Ether extract & $3.4 \pm 0.0$ & $3.5 \pm 0.1$ & $2.8 \pm 0.2$ & $2.9 \pm 0.2$ \\
\hline Ash & $10.8 \pm 0.1$ & $9.1 \pm 0.7$ & $9.6 \pm 0.3$ & $9.8 \pm 0.4$ \\
\hline Starch & - & - & $10.8 \pm 1.5$ & $3.0 \pm 0.9$ \\
\hline NDF & $42.5 \pm 1.4$ & $47.3 \pm 0.3$ & $38.2 \pm 1.4$ & $44.1 \pm 1.0$ \\
\hline $\mathrm{ADF}$ & $30.0 \pm 0.4$ & $32.3 \pm 1.1$ & $25.3 \pm 1.2$ & $28.3 \pm 1.4$ \\
\hline ADL & $4.7 \pm 0.3$ & $5.1 \pm 0.1$ & $3.6 \pm 0.5$ & $4.1 \pm 0.4$ \\
\hline $\mathrm{NE}_{\mathrm{L}}, \mathrm{MJ} / \mathrm{kg}$ of $\mathrm{DM}$ & $6.13 \pm 0.05$ & $5.50 \pm 0.18$ & $6.41 \pm 0.09$ & $6.18 \pm 0.09$ \\
\hline
\end{tabular}

${ }^{1} \mathrm{CON}=$ control diet; WBBP $=$ wheat bran and dried sugar beet pulp diet.

${ }^{2}$ Utilizable crude protein at the duodenum (GfE, 2001).

${ }^{3} \mathrm{RNB}=$ ruminal $\mathrm{N}$ balance (GfE, 2001).

\section{Chewing Behavior and Milk Performance Data}

Despite higher NDF intakes, no effects of the dietary treatment on eating and ruminating activity in minutes per day, as well as per kilogram of DMI, were observed (Table 4). This is in agreement with results of Dann et al. (2014), who also observed no effects on chewing activity when replacing corn with wheat middlings and sugar beet pulp. This indicates that the additional fiber provided by WBBP diet was not physically effective, because physically effective fiber would have stimulated chewing activity (Mertens, 1997; Zebeli et al., 2012). Earlier works suggest that NDF from NFFS are effective to a certain extent, particularly when diets are low in forage fiber (Swain and Armentano, 1994; Bradford and Mullins, 2012), and grinding did not reduce the effectiveness of sugar beet pulp (Teimouri Yansari, 2014). However, compared with the mean chewing activity of

Table 3. Daily DM, nutrient, and energy intake of cows fed diets differing in concentrate type

\begin{tabular}{lcccr}
\hline & \multicolumn{2}{c}{ Diet $^{1}$} & & \\
\cline { 2 - 3 } Item & CON & WBBP & SEM & $P$-value \\
\hline Total DMI, kg/d & 18.1 & 18.5 & 0.33 & 0.488 \\
Nutrient intake, kg/d & & & & \\
NDF & 6.87 & 8.15 & 0.14 & $<0.001$ \\
ADF & 4.54 & 5.23 & 0.09 & $<0.001$ \\
ADL & 0.64 & 0.75 & 0.01 & $<0.001$ \\
CP & 2.44 & 2.55 & 0.05 & 0.083 \\
uCP & 2.56 & 2.57 & 0.05 & 0.670 \\
Starch & 1.99 & 0.53 & 0.03 & $<0.001$ \\
Ether extract & 0.51 & 0.55 & 0.01 & $<0.001$ \\
Total DMI, \% of BW & 2.85 & 2.90 & 0.05 & 0.497 \\
NDF intake, \% of BW & 1.08 & 1.28 & 0.02 & $<0.001$ \\
Energy, MJ of NE $\mathrm{L}_{\mathrm{L}}$ & 117 & 114 & 2.1 & 0.388 \\
\hline
\end{tabular}

${ }^{1} \mathrm{CON}=$ control diet; $\mathrm{WBBP}=$ wheat bran and dried sugar beet pulp diet.

${ }^{2}$ Utilizable crude protein at the duodenum (GfE, 2001).
$691 \mathrm{~min} / \mathrm{d}$ summarized from various studies in highproducing dairy cows (Zebeli et al., 2006), the total chewing activity of $983 \mathrm{~min} / \mathrm{d}$ in CON in the present study (Table 4) was already very high, which most likely does not allow further increasing of chewing activity through providing additional dietary fiber. Therefore, the higher fiber intake for cows in the WBBP group resulted in a $12 \%$ lower chewing activity per kilogram of NDF ingested.

Milk yield and milk composition were not affected by the dietary treatment (Table 5). This finding is in agreement with several earlier studies which found that by-products can replace different portions of grains up to $100 \%$ without impairing milk production at different performance levels (Voelker and Allen, 2003; Dann et al., 2014; Ertl et al., 2015b). In this feeding trial, the overall level of ECM production $(22.5-22.7 \mathrm{~kg} / \mathrm{d})$ was only moderate compared with other feeding trials investigating the substitution of fiber-rich by-products for grain concentrates. Indeed, the studies by Voelker and Allen (2003) and Dann et al. (2014) reported daily

Table 4. Chewing behavior of cows fed diets differing in concentrate type

\begin{tabular}{|c|c|c|c|c|}
\hline \multirow[b]{2}{*}{ Item } & \multicolumn{2}{|c|}{ Diet $^{1}$} & \multirow[b]{2}{*}{ SEM } & \multirow[b]{2}{*}{$P$-value } \\
\hline & $\mathrm{CON}$ & WBBP & & \\
\hline \multicolumn{5}{|l|}{ Eating time } \\
\hline $\mathrm{min} / \mathrm{d}$ & 431.0 & 442.7 & 15.4 & 0.592 \\
\hline $\min / \mathrm{kg}$ of $\mathrm{DM}$ & 23.9 & 24.4 & 0.8 & 0.697 \\
\hline $\mathrm{min} / \mathrm{kg}$ of $\mathrm{NDF}$ & 63.1 & 55.3 & 2.0 & 0.009 \\
\hline \multicolumn{5}{|l|}{ Ruminating time } \\
\hline $\min / \mathrm{d}$ & 551.8 & 565.5 & 8.8 & 0.280 \\
\hline $\mathrm{min} / \mathrm{kg}$ of $\mathrm{DM}$ & 30.6 & 31.2 & 0.5 & 0.408 \\
\hline $\mathrm{min} / \mathrm{kg}$ of $\mathrm{NDF}$ & 80.7 & 70.8 & 1.2 & $<0.001$ \\
\hline Total chewing, $\min / \mathrm{d}$ & 982.9 & 1008.3 & 12.1 & 0.147 \\
\hline
\end{tabular}


Table 5. Milk production data, live weight change, and efficiency indicators of cows fed diets differing in concentrate type

\begin{tabular}{lcccc}
\hline & \multicolumn{2}{c}{ Diet $^{1}$} & & \\
\cline { 2 - 3 } Item & CON & WBBP & SEM & $P$-value \\
\hline Milk parameters & & & & \\
ECM yield, kg/d & 22.5 & 22.7 & 0.7 & 0.796 \\
Protein, \% & 3.23 & 3.21 & 0.07 & 0.925 \\
Fat, \% & 4.29 & 4.23 & 0.12 & 0.741 \\
Urea, $\mathrm{mg} / 100 \mathrm{~mL}$ & 13.3 & 13.7 & 0.7 & 0.611 \\
SCC, $\mathrm{n} \times 10^{3} / \mathrm{mL}$ & 125 & 80 & 30 & 0.286 \\
Live weight change, $\mathrm{kg} / \mathrm{d}$ & -0.16 & 0.03 & 0.11 & 0.253 \\
Efficiency parameters & & & & \\
Feed conversion efficiency, kg of ECM per kg of DMI & 1.27 & 1.25 & 0.01 & 0.102 \\
N efficiency, milk N in \% of N intake & 29.7 & 28.3 & 0.7 & 0.169 \\
\hline
\end{tabular}

${ }^{1} \mathrm{CON}=$ control diet; WBBP $=$ wheat bran and dried sugar beet pulp diet.

performance levels between 34.0 and $35.5 \mathrm{~kg}$ of ECM or ranging from 40.0 to $40.8 \mathrm{~kg}$ of ECM when corn was partly replaced with sugar beet pulp or sugar beet pulp and wheat middlings, respectively. However, in grass-based dairy production systems such as those in Austria, milk performance is often limited. Therefore, performance levels presented herein are representative and the results allow conclusions on the use of NFFS regarding their potential to increase the NFP in such production systems with high-forage diets and moderate performance levels.

\section{Feed Conversion Efficiency and N Efficiency}

Feed conversion efficiency (FCE), expressed as kilograms of ECM per kilogram of DMI, did not differ between treatments (Table 5), but the overall level of FCE in this trial (1.25 and 1.27) was somewhat lower as compared with other studies. For example, Khalili et al. (2002) reported FCE between 1.37 and 1.40 for organic dairy cows with similar milk performance, and Dann et al. (2014) observed FCE between 1.62 and 1.68 $\mathrm{kg}$ of milk/kg of DMI for high-yielding dairy cows fed diets differing in their starch content. Considering that feed costs make up a high percentage of the total costs of milk production, FCE has tremendous effects on the profitability of dairy production (Beever and Doyle, 2007) and it also has a strong effect on the estimated environmental effect of animal production systems in general (Peters et al., 2014). However, as argued by Wilkinson (2011), calculations of FCE fail to consider the ability of livestock systems to use feedstuffs which are not human-edible. On the contrary, it can be argued that FCE in dairy cows might even be misleading regarding the animals' NFP, a factor that may become more important in the future (Foley et al., 2011). The reason for this is that as milk yield increases, the re- sulting increase in feed intake is inadequate to meet the animals' increased nutrient demands, resulting in a need for more nutrient-dense diets, which is often achieved by increasing the percentage of (potentially human-edible) concentrates in the ration (Knaus, 2013). On one hand this leads to an increase in FCE, on the other the increased input of potentially humanedible feedstuffs might result in a reduced NFP. The problem of the tradeoff between increased FCE and higher human-edible inputs in beef production has been addressed before (Council for Agricultural Science and Technology, 1999). From the perspective of NFP, FCE must be interpreted with caution.

Efficiency of $\mathrm{N}$ use (milk $\mathrm{N}$ in percent of $\mathrm{N}$ intake) was not affected by treatment. Nitrogen efficiencies in both treatment groups were higher than the $24.1 \%$ observed in our earlier feeding trial (Ertl et al., 2015b), which can be explained by the lower $\mathrm{CP}$ content in the diet (Colmenero and Broderick, 2006), but $\mathrm{N}$ use efficiency was slightly lower than the potential 30 to $35 \%$ stated in Powell et al. (2010). Efficiency of feed $\mathrm{N}$ use in dairy production is generally higher than $\mathrm{N}$ use in meat production, which is why Erisman et al. (2008) suggest the amount of protein from dairy compared with protein from meat will increase when human diets are optimized for $\mathrm{N}$ conversion efficiency. This advantage of dairy production might be even more profound when the amount of potentially human-edible $\mathrm{N}$ fed to dairy cows is reduced.

\section{heFCE and NFP}

The use of heFCE has been suggested to include the aspect of the feed versus food competition in FCE (Wilkinson, 2011; Ertl et al., 2015a). Although Peters et al. (2014) argued that the approach of analyzing the return on human-edible inputs (in this paper as heFCE 
and NFP) ignores land use efficiencies of livestock, these approaches are still relevant because feeding less potential human food to livestock is a key issue in improving sustainable livestock production (Eisler et al., 2014). Because estimating the potential human-edible fraction of feedstuffs is one of the main challenges in the debate about feed versus food competition (Le Cotty and Dorin, 2012), we chose min and max scenarios for potentially human-edible fractions to represent possible ranges of recovery rates for potentially human-edible nutrients from feedstuffs. However, these are only practicable under the current feeding and production conditions and may vary in future scenarios.

Dietary treatment had strong effects on heFCE and NFP under both scenarios ( $\min$ and max, Table 6). Compared with CON, the heFCE in WBBP for the max scenario was 6.8 and 5.3 times higher for energy and protein, respectively. For the min scenario, humanedible inputs in the WBBP group were zero, thus according to its definition, heFCE could not be calculated (division by zero). Human-edible FCE was always higher than 1, even when feeding CON; thus, NFP was always positive. Although this is in agreement with our earlier feeding trial, where we found heFCE between 1.4 and 5.6 (Ertl et al. 2015b), and with model calculations for dairy cows under common feeding strategies in the United Kingdom, where heFCE of 2.1 for energy and 1.4 for protein were reported (Wilkinson, 2011), heFCE are not necessarily higher than 1 . A recent evaluation of 30 Austrian dairy farms, for example, has shown that at the farm gate level only about half of the farms showed a heFCE $>1$ (Ertl et al., 2015a). For a least-cost ration based on common feeds under typical California conditions, Oltjen and Beckett (1996) also calculated heFCE of only 0.57 for energy and 0.96 for protein.

Our calculations of heFCE for 5 different diets based on data from Dann et al. (2014) and Voelker and Allen (2003) revealed heFCE between 0.4 and 3.1 (Table 6). For the max scenario, only the low-starch diet reported in Dann et al. (2014) achieved an heFCE $>1$ for energy, whereas no reported diet resulted in an heFCE $>1$ for protein. Thus, despite the higher milk performance in these studies (34.0-40.8 $\mathrm{kg}$ of ECM) as compared with the present study (on average, $22.6 \mathrm{~kg}$ of ECM), NFP was, with only one exception for energy, always negative under the max scenario. These results suggest that the milk production level alone does not allow conclusions to be drawn on the NFP of a dairy production system. Comparing diets within the same studies (same forage-to-concentrate ratios), as the inclusion rate of fibrous by-products in the diets increases at the expense of grains [CON vs. WBBP in the present study, high-starch vs. low-starch diet in Dann et al. (2014),

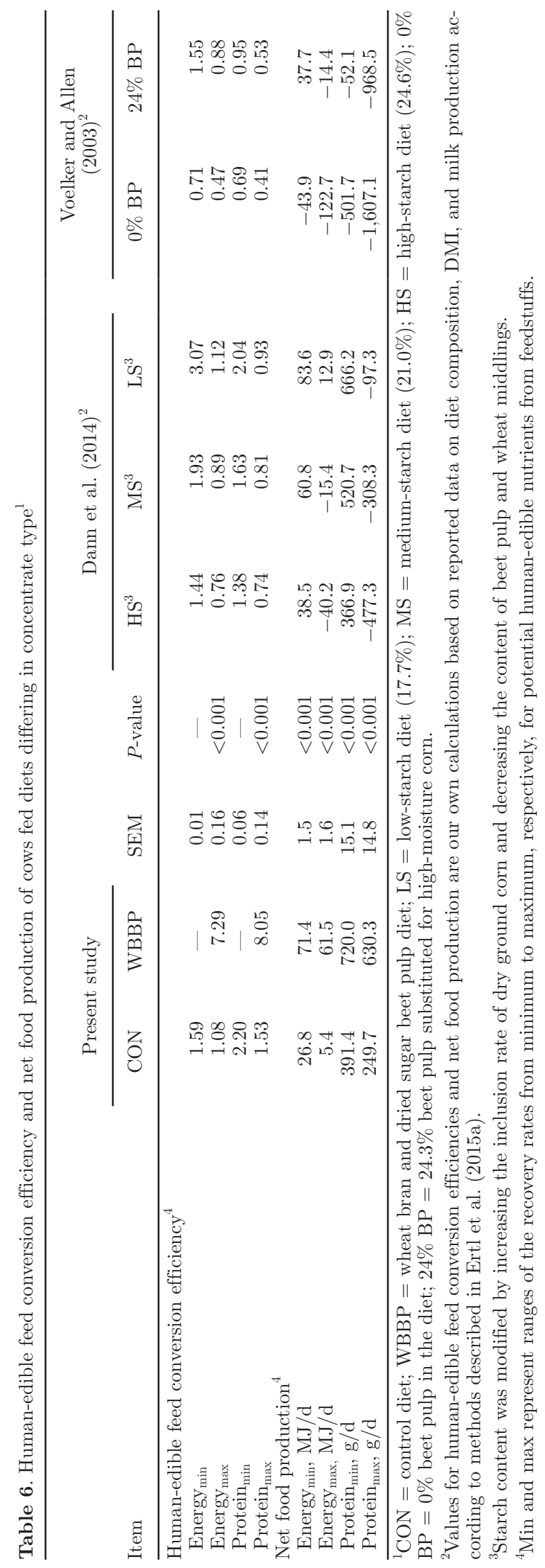


and $0 \%$ beet pulp vs. $24 \%$ beet pulp in Voelker and Allen (2003)], the NFP increases. Hence, not only the amount of concentrate in the diet, but also its composition strongly affects the NFP.

The highest NFP for protein was observed for the WBBP diet under the min scenario $(720 \mathrm{~g} / \mathrm{d})$. Assuming protein requirements of $58 \mathrm{~g} / \mathrm{d}$ for an average adult person weighing $70 \mathrm{~kg}$ (WHO/FAO/UNU, 2007), this implies that each cow under this scenario provided the daily amount of high-quality protein to meet the requirements of more than 12 people. However, diets with high amounts of potentially human-edible grains can also result in a negative NFP of over $1.5 \mathrm{~kg}$ of protein per cow and day, as shown with the $0 \%$ beet pulp diet in Voelker and Allen (2003). Therefore, statements on the inefficiency of raising animals to produce human food, for example in Sabaté and Soret (2014), should not be generalized and need more differentiation.

Besides the previously mentioned challenge of estimating the human-edible fractions of feedstuffs, another limitation of relating human-edible output to human-edible input in dairy cows is that this approach includes only quantities and fails to take into account quality differences between the human-edible input and output. Whereas, on the energy side, these differences are most likely of only minor relevance, they are more distinct for protein, as animal proteins are generally of a higher nutritional value as compared with plant proteins. This superiority of animal protein sources over plant proteins is often highlighted in the discussion about the role of livestock in food security (FAO, 2011; Council for Agricultural Science and Technology, 2013; Smith et al., 2013), but it has also been frequently ignored when comparing the sustainability of animal and plant-based diets (Pimentel and Pimentel, 2003; Sabaté and Soret, 2014). In addition to several different existing methods, the digestible indispensable amino acid score (DIAAS) was recently proposed by FAO (2013) as a new and preferred method to determine protein quality. Whereas a DIAAS of 1.22 has been reported for whole milk powder (FAO, 2013), the potential humanedible inputs in our study had significantly lower scores, such as $0.47,0.51$, and 0.54 , for rye, barley, and corn, respectively (Cervantes-Pahm et al., 2014), or 0.64 for peas [own calculation based on values in FAO (2013)]. The DIAAS greater than 1 for whole milk powder indicates the potential to complement lower quality protein in dietary mixtures (FAO, 2013). The fact that the human-edible output of milk has a DIAAS about twice as high as human-edible protein input sources suggests that including changes in protein quality might lead to strong additional increases in heFCE (up to 2 times higher) and also in the NFP for protein when humanedible input is greater than 0 .

\section{CONCLUSIONS}

The use of wheat bran and sugar beet pulp as sole supplements in a grass-based diet has been shown to increase heFCE and NFP in dairy cows compared with common grain-based concentrates. The inclusion of additional fiber via these NFFS in a high-forage diet did not impair DMI, milk performance, or total chewing behavior. The fact that cows used in our study were already post-peak limits the validity of this conclusion for high-yielding dairy cows in peak lactation. Intensification of the use of human-inedible (fiber-rich) by-products would help the dairy industry counter the general criticism of inefficient nutrient use in livestock systems by achieving higher heFCE and NFP, especially when changes in protein quality are also considered. However, increasing the use of fiber-rich supplements might limit milk performance per cow, which is why trade-offs between optimizing heFCE or NFP and currently existing efficiency or sustainability criteria might arise.

\section{ACKNOWLEDGMENTS}

The authors are grateful to the Austrian Federal Ministry of Agriculture, Forestry, Environment and Water Management (Vienna, Austria), Bio Austria (Linz, Austria), the Salzburger Landesregierung (Salzburg, Austria), Raiffeisenverband Salzburg (Salzburg, Austria), and the Werner Lampert Beratungsges.m.b.H. (Vienna, Austria) for funding this research. Furthermore, we are thankful to the Secondary Agriculture and Forestry College Ursprung (Salzburg, Austria) for housing the experiment, to the farm staff, especially Franz Grießner, for helping with the experimental work, as well as to Kathleen Knaus (WU, Vienna University of Economics and Business, Vienna, Austria) for editing assistance.

\section{REFERENCES}

Beever, D. E., and P. T. Doyle. 2007. Feed conversion efficiency as a key determinant of dairy herd performance: A review. Aust. J. Exp. Agric. 47:645-657.

Bhattacharya, A. N., and W. F. Lubbadah. 1971. Feeding high levels of beet pulp in high concentrate dairy rations. J. Dairy Sci. 54:95-99.

Bradford, B. J., and C. R. Mullins. 2012. Strategies for promoting productivity and health of dairy cattle by feeding nonforage fiber sources. J. Dairy Sci. 95:4735-4746.

Bradford, G. E. 1999. Contributions of animal agriculture to meeting global human food demand. Livest. Prod. Sci. 59:95-112.

Cervantes-Pahm, S. K., Y. H. Liu, and H. H. Stein. 2014. Digestible indispensable amino acid score and digestible amino acids in eight cereal grains. Br. J. Nutr. 111:1663-1672.

Chase, L. E. 2007. Can we feed less starch to our cows? Pages 213-220 in Proc. Cornell Nutr. Conf. for Feed Manufac., Syracuse, NY. Cornell University, Ithaca, NY. 
Colmenero, J. J. O., and G. A. Broderick. 2006. Effect of dietary crude protein concentration on milk production and nitrogen utilization in lactating dairy cows. J. Dairy Sci. 89:1704-1712.

Council for Agricultural Science and Technology. 1999. Animal agriculture and global food supply. Task Force Report No. 135. Council for Agricultural Science and Technology, Ames, IA.

Council for Agricultural Science and Technology. 2013. Animal feed vs. human food: Challenges and opportunities in sustaining animal agriculture toward 2050. Issue Paper 53. Council for Agricultural Science and Technology, Ames, IA.

Dann, H. M., H. A. Tucker, K. W. Cotanch, P. D. Krawczel, C. S. Mooney, R. J. Grant, and T. Eguchi. 2014. Evaluation of lower-starch diets for lactating Holstein dairy cows. J. Dairy Sci. 97:7151-7161

Eisler, M. C., M. R. F. Lee, J. F. Tarlton, G. B. Martin, J. Beddington, J. A. J. Dungait, H. Greathead, J. X. Liu, S. Mathew, H. Miller, T. Misselbrook, P. Murray, V. K. Vinod, R. Van Saun, and M. Winter. 2014. Steps to sustainable livestock. Nature 507:32-34

Erisman, J. W., M. A. Sutton, J. Galloway, Z. Klimont, and W. Winiwarter. 2008. How a century of ammonia synthesis changed the world. Nat. Geosci. 1:636-639.

Ertl, P., H. Klocker, S. Hoertenhuber, W. Knaus, and W. Zollitsch. 2015a. The net contribution of dairy production to human food supply: The case of Austrian dairy farms. Agric. Syst. 137:119-127.

Ertl, P., W. Knaus, B. U. Metzler-Zebeli, F. Klevenhusen, R. KhiaosaArd, and Q. Zebeli. 2015c. Substitution of common concentrates with by-products modulated ruminal fermentation, nutrient degradation, and microbial community composition in vitro. J. Dairy Sci. 98:4762-4771.

Ertl, P., Q. Zebeli, W. Zollitsch, and W. Knaus. 2015b. Feeding of byproducts completely replaced cereals and pulses in dairy cows and enhanced edible feed conversion ratio. J. Dairy Sci. 98:1225-1233.

Fadel, J. G. 1999. Quantitative analyses of selected plant by-product feedstuffs, a global perspective. Anim. Feed Sci. Technol. 79:255268.

FAO. 2011. World Livestock 2011-Livestock in Food Security. FAO, Rome, Italy.

FAO. 2013. Dietary Protein Quality Evaluation in Human NutritionReport of an FAO Expert Consultation. Food and Nutrition Paper 92. FAO, Rome, Italy.

FAO. 2015. FAOSTAT - Production quantities by country. Accessed Sept. 25, 2015. http://faostat3.fao.org/browse/Q/QC/E.

Foley, J. A., N. Ramankutty, K. A. Brauman, E. S. Cassidy, J. S. Gerber, M. Johnston, N. D. Mueller, C. O'Connell, D. K. Ray, P. C. West, C. Balzer, E. M. Bennett, S. R. Carpenter, J. Hill, C. Monfreda, S. Polasky, J. Rockstrom, J. Sheehan, S. Siebert, D. Tilman, and D. P. M. Zaks. 2011. Solutions for a cultivated planet. Nature 478:337-342.

GfE. 2001. Empfehlungen zur Energie und Nährstoffversorgung der Milchkühe und Aufzuchtrinder. DLG-Verlag, Frankfurt am Main, Germany.

Gill, M. 2013. Converting feed into human food: The multiple dimensions of efficiency. Pages 1-14 in Optimization of Feed Use Efficiency in Ruminant Prodution Systems. FAO Animal Production and Health Proc. No. 16. H. P. S. Makkar and D. Beever, ed. FAO and Asian-Australasian Association of Anim. Prod. Societies, Rome, Italy.

Hemingway, R. G., J. J. Parkins, and J. Fraser. 1986. Sugar-beet pulp products for dairy-cows. Anim. Feed Sci. Technol. 15:123-127.

INRA, CIRAD, AFZ, and FAO. 2015. Feedipedia-Animal Feed Resources Information System. Accessed Sept. 29, 2015. http:// feedipedia.org.
Khalili, H., E. Kuusela, M. Suvitie, and P. Huhtanen. 2002. Effect of protein and energy supplements on milk production in organic farming. Anim. Feed Sci. Technol. 98:103-119.

Knaus, W. 2013. Food security and dairy cow feeding: the necessity for a paradigm shift. Agric. Conspec. Sci. 78:149-152.

Le Cotty, T., and B. Dorin. 2012. A global foresight on food crop needs for livestock. Animal 6:1528-1536.

Littell, R. C., P. R. Henry, and C. B. Ammerman. 1998. Statistical analysis of repeated measures data using SAS procedures. J. Anim. Sci. 76:1216-1231.

Mertens, D. R. 1997. Creating a system for meeting the fiber requirements of dairy cows. J. Dairy Sci. 80:1463-1481.

NRC. 2001. Nutrient Requirements of Dairy Cattle. 7th rev. ed. Natl. Acad. Press, Washington, DC.

Oltjen, J. W., and J. L. Beckett. 1996. Role of ruminant livestock in sustainable agricultural systems. J. Anim. Sci. 74:1406-1409.

Peters, C. J., J. A. Picardy, A. Darrouzet-Nardi, and T. S. Griffin. 2014. Feed conversions, ration compositions, and land use efficiencies of major livestock products in U.S. agricultural systems. Agric. Syst. 130:35-43.

Pimentel, D., and M. Pimentel. 2003. Sustainability of meat-based and plant-based diets and the environment. Am. J. Clin. Nutr. 78:660S-663S.

Powell, J. M., C. J. P. Gourley, C. A. Rotz, and D. M. Weaver. 2010. Nitrogen use efficiency: A potential performance indicator and policy tool for dairy farms. Environ. Sci. Policy 13:217-228.

Sabaté, J., and S. Soret. 2014. Sustainability of plant-based diets: Back to the future. Am. J. Clin. Nutr. 100:476S-482S.

Smith, J., K. Sones, D. Grace, S. MacMillan, S. Tarawali, and M. Herrero. 2013. Beyond milk, meat, and eggs: Role of livestock in food and nutrition security. Anim. Front. 3:6-13.

Swain, S. M., and L. E. Armentano. 1994. Quantitative evaluation of fiber from nonforage sources used to replace alfalfa silage. J. Dairy Sci. 77:2318-2331.

Teimouri Yansari, A. 2014. Physically effectiveness of beet pulp-based diets in dairy cows as assessed by responses of feed intake, digestibility, chewing activity and milk production. J. Anim. Physiol. Anim. Nutr. (Berl.) 98:158-168.

VDLUFA. 1993. Handbuch der Landwirtschaftlichen Versuchs und Untersuchungsmethodik (VDLUFA-Methodenbuch), Bd. III: Die Chemische Untersuchung von Futtermitteln. VDLUFA-Verlag, Darmstadt, Germany.

Voelker, J. A., and M. S. Allen. 2003. Pelleted beet pulp substituted for high-moisture corn: 1. Effects on feed intake chewing behavior, and milk production of lactating dairy cows. J. Dairy Sci. $86: 3542-3552$

WHO/FAO/UNU. 2007. Protein and amino acid requirements in human nutrition. Report of a Joint WHO/FAO/UNU expert consultation WHO tech. Rep. Ser. Vol. 935. WHO Press, Geneva, Switzerland.

Wilkinson, J. M. 2011. Re-defining efficiency of feed use by livestock. Animal 5:1014-1022.

Zebeli, Q., J. R. Aschenbach, M. Tafaj, J. Boguhn, B. N. Ametaj, and W. Drochner. 2012. Role of physically effective fiber and estimation of dietary fiber adequacy in high-producing dairy cattle. J. Dairy Sci. 95:1041-1056.

Zebeli, Q., M. Tafaj, H. Steingass, B. Metzler, and W. Drochner. 2006. Effects of physically effective fiber on digestive processes and milk fat content in early lactating dairy cows fed total mixed rations. J. Dairy Sci. 89:651-668. 